\title{
MAMMALS COLLECTED BY THE SMITHSONIAN-HARVARD EXPEDITION TO THE ALTAI MOUNTAINS, 1912.
}

\author{
By N. Hollister, \\ Assistant Curator, Division of Mammals, United States National Museum.
}

\section{INTRODUCTION.}

The fauna of the Altai Mountains, Siberia and Mongolia, has been virtually unrepresented in American museums. The United States National Museum, therefore, gladly welcomed the generous invitation of Dr. Theodore Lyman to participate, with the Museum of Comparative Zoölogy at Harvard, in a zoological expedition to that part of Asia during the summer of 1912, and I was detailed as its representative for field work.

Doctor Lyman's plans were to follow the routes of the Demidoff ${ }^{1}$ and the Swayne ${ }^{2}$ sporting expeditions to the country of the famous Altai wild sheep, on the Mongolian side of the Little Altai, and, while securing good specimens of the sheep, ibex, and other large game of that region, to make the most of the opportunity afforded to collect the smaller vertebrate animals for the two museums. The resulting trip extended to nearly four months, but so much time was taken by the long journey to and from the scene of operations that only about thirty-five days of actual collecting were enjoyed. We were fortunate, however, in our selections of camp sites in three different physiographical regions, and by working at high pressure when the opportunity offered we were enabled to make much greater and more varied collections than we had anticipated. Doctor Lyman, whose time was chiefly devoted to the collecting of large game, had engaged as my assistant in the work of collecting the smaller vertebrates Conrad Kain, of Vienna. Without the assistance of this indefatigable mountaineer, whose resourcefulness, ability, and good companionship are known to Alpine Club people of many countries, the collection would be much smaller than it is. The collection of

\footnotetext{
1 E. Demidoff, After Wild Sheep in the Altai and Mongolia, pp. i-xii; 1-324; numerous illustrations and map, London, 1900.

2 H. G. C. Swayne, Through the Highlands of Siberia, pp. 1-xiv; 1-259; 60 illustrations and map, London, 1904.
} 
mammals, including about 350 specimens, has been turned over to the National Museum for determination. An account of the birds, with descriptions of three new forms, has been published by $\mathrm{Mr}$. Outram Bangs. ${ }^{1}$ The collections have now been divided between the two institutions.

\section{ITINERARY.}

Having been joined by Kain in London the latter part of May, 1912, we proceeded to St. Petersburg, completed the arrangements for permits with the Russian officials, engaged the services of an interpreter, and departed over the Siberian Railway, June 8, for the East. On the morning of June 12 we left the train at Novonikolævsk, on the Obi River, and before evening were embarked on a steamer for the upper river. Biisk, the head of navigation for steamers, was reached on the night of June 15. Arrangements for horses and tarantasses were made for the first stage of the trip over the post road to the southward and on the morning of June 18 we began the long trip by team to the last Russian outpost, Kosh-Agatch. At Ust-Inya, something over half the distance, we negotiated with Kalmuks for horses for our pack trip beyond Kosh-Agatch, and these reached Kosh-Agatch with us June 28. A delay of two days at Ust-Inya gave me the opportunity for setting a few traps, and the first mammals were collected there.

Kosh-Agatch, on the Chuisaya (or Tchouia) Steppe, is the end of the road, and from here on to the Mongolian border the trip was by pack and saddle horses. Our party now consisted of Doctor Lyman, Kain, and myself, and the Russian interpreter and four native Tartars and Kalmuks, with 15 horses. Two days' journey across the desert steppe and up the valley of the headwaters of the Chuya (or Tchouia) River brought us to the "last timber," a few larch trees (Larix sibirica) near Tschornia Creek, a branch of the Chuya near the Mongolian border, in Tchegan-Burgazi Pass. Here a suitable camp was pitched and I settled down, July 1, with Kain and one Tartar camp man, to make a collection of the mammals and birds of the Little Altai. Doctor Lyman, with the rest of the outfit, pushed on through the pass for a circle of the range in Mongolia after big game, particularly sheep and ibex.

Except for a few larches in some of the valleys on the Siberian side the region is without timber, though there is evidence that other sheltered slopes have been deforested within comparatively recent times. Trees were, however, never plenty, and the constant drain on the limited growth by Kirghiz, Kalmuk, and Tartar has almost cleaned up the remnant. The Mongolian side is absolutely without bush or tree, and as on the Chuisaya Steppe, "tezek," or dry horse- 
dung is the principal fuel for cooking. The country about the site of our Tchegan-Burgazi camp is steep rolling mountains, with rocky slides and beautiful alpine tops. Close by, to the southwest, is the snow-capped border range, and from the higher points the country as far as can be seen is rolling grassy alps, interspersed with rocky, desert areas, and snowy ranges. The altitude of our camp in the valley bottom was 8,300 feet, and the highest point near camp for a day's collecting, about 12,000 feet. The rolling alplands average about 9,000 to 10,000 feet.

While we were engaged in work in the Tchegan-Burgazi, Doctor Lyman had a most interesting and successful trip into Mongolia, by way of the Tchegan-Burgazi Pass, returning by the Tarkuta Pass and over the range to our camp. His hunting was chiefly in the Suok Plain and Taylüke Valley country, desert mountains and plateaux, and his notes on this trip will be found beyond with the text on the sheep, ibex, and other game animals.

The Tchegan-Burgazi camp was occupied, and active collecting carried on until July 27, when, Doctor Lyman having returned, we broke camp and moved northward to the center of the Chuisaya Steppe. - One night's trapping and a day of shooting and preparing specimens gave us a small collection of steppe species and we reached Kosh-Agatch on the return trip July 29. Two days were occupied with packing and preparing for the homeward journey, the plans for which included a week's stay in the heavily forested mountains north of Ongudai, and on July 31 we departed over the post road to the north.

August 5 we reached the point we had selected as a good place to work in the forested mountains, and pitched camp at 6,875 feet, just in the edge of the forest, at the north end of Tapucha Pass, about 5 miles south of the village of Tapucha. This locality is about 125 miles southeast of Biisk. The camp was in a beautiful forest of nut pine (Pinus cembra), heavy with moisture and thick with underbrush and windfalls, with alps and rocky tops near by, and snow peaks in the distance. Here collecting was carried on until August 11, when, the weather having warned us of the severe mountain winter approaching, and our time being nearly up, we left on the last part of the tarantass trip, and reached Biisk late on the night of August 14.

The trip by steamer down the Obi was made without incident worthy of note, and on August 21 we took the westbound train at Novonikolævsk for St. Petersburg. We were fortunate in many ways, and though the weather throughout our stay in the Altais was unspeakably bad, and rain, sleet, hail, and snow the rule rather than the exception, yet the trip passed off without serious trouble. We were treated with great kindness and attention by the Russian officials at every point, and the settlers along the post roads always gave us the best to be had. 
Thirteen new species and subspecies of mammals, collected on this expedition, have been described in preliminary papers. These are:

Sorex roboratus.

Myotis petax.

Mustela lymani.

Mustela lineiventer.

Phodopus crepidatus.

Myopus morulus.

Apodemus nigritalus.
Sicista napæa.

Allactaga grisescens.

Eutamias asiaticus altaicus.

Ochotona nitida.

Lepus quercerus.

Procapra altaica.

\section{ANNOTATED LIST OF SPECIES.}

\section{SOREX ARANEUS BOREALIS Kastschenko.}

1905. Sorex araneus borealis Kastschenko, Обз. Млекопит. Зап. Сибири и Туркестана [Synopsis mammals western Siberia and Turkestan], I, Chiroptera and Insectivora, p. 85. Tomsk.

Six specimens from alpine meadows at 9,000 to 9,500 feet in Tchegan-Burgazi Pass, and three specimens from the forests near Tapucha at 6,400 feet. The series, collected in July and August, contains specimens in both the summer and winter pelages. This race averages somewhat smaller than any European form of araneus, except the Spanish granarius. It is otherwise very like true araneus. No definite type-locality is given in the original description, but the account is largely based on specimens collected by Middendorff in the "far north." The range, as given by Kastschenko, includes all of extreme northern Siberia, all the mountain ranges from the Altai eastward, and possibly all of eastern Siberia.

Measurements of Sorex araneus borealis from the Altai Mountains, Siberia.

\begin{tabular}{|c|c|c|c|c|c|c|c|c|c|c|c|c|c|}
\hline Locality. & 岕 & $\begin{array}{l}\dot{x} \\
\ddot{D}\end{array}$ & 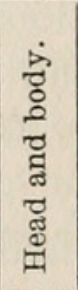 & 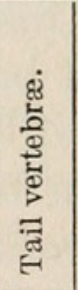 & 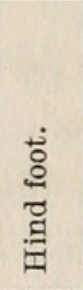 & 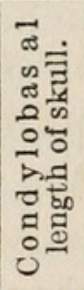 & 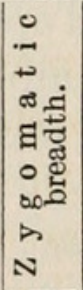 & 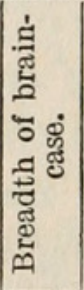 & 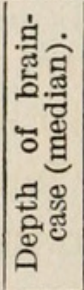 & 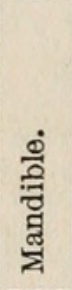 & 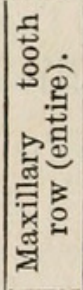 & 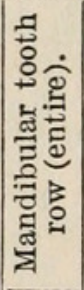 & $\begin{array}{l}\text { State of wear } \\
\text { of teeth. }\end{array}$ \\
\hline $\begin{array}{r}\text { Tchegan-Bur- } \\
\text { gazi Pass... } \\
\text { Do........ } \\
\text { Do....... } \\
\text { Do........ } \\
\text { Do....... } \\
\text { Do........ } \\
\text { Tapucha...... } \\
\text { Do....... } \\
\text { Do....... }\end{array}$ & $\begin{array}{l}175429 \\
175431 \\
175432 \\
175433 \\
175434 \\
175430 \\
175437 \\
175435 \\
175438\end{array}$ & $\begin{array}{c}\text { Male.... } \\
\ldots . \text { do...... } \\
\ldots . \text { do..... } \\
\ldots \text {. do..... } \\
\ldots . \text { do..... } \\
\text { Female.. } \\
\text { Male.... } \\
\text { Female. } \\
\ldots . \text { do..... }\end{array}$ & $\begin{array}{r}m m . \\
66 \\
64 \\
63 \\
67 \\
61 \\
61 \\
64 \\
67 \\
62\end{array}$ & $\begin{array}{c}m m . \\
32 \\
37 \\
38 \\
31 \\
37 \\
36 \\
37 \\
40 \\
39\end{array}$ & $\begin{array}{l}m m . \\
11.5 \\
12.5 \\
12.5 \\
12.5 \\
12 \\
12 \\
12 \\
12.5 \\
12\end{array}$ & $\begin{array}{l}m m . \\
17.1 \\
17.6 \\
17.5 \\
17.4 \\
\dddot{17.5} \\
17.6 \\
\dddot{17.6}\end{array}$ & \begin{tabular}{l}
$m m$. \\
5 \\
5 \\
4.9 \\
5 \\
5 \\
4.9 \\
5 \\
\hdashline 5
\end{tabular} & \begin{tabular}{|l|}
$m m$. \\
9.1 \\
8.8 \\
8.7 \\
9.1 \\
\hdashline $9 .$. \\
9 \\
9.1 \\
9.5 \\
9.2
\end{tabular} & $\begin{array}{l}m m . \\
4.5 \\
5.1 \\
5 \\
4.7 \\
\because . . \\
5.1 \\
4.6 \\
5.4 \\
5.2\end{array}$ & $\begin{array}{l}m m . \\
9 \\
9.1 \\
9 \\
9.1 \\
8.9 \\
9 \\
9.5 \\
9.7 \\
9.5\end{array}$ & $\begin{array}{l}m m . \\
7.5 \\
7.9 \\
7.9 \\
7.5 \\
7.5 \\
7.9 \\
7.9 \\
8.1 \\
8\end{array}$ & $\begin{array}{l}m m . \\
6.7 \\
7.4 \\
7.4 \\
7 \\
7.1 \\
7.2 \\
7.4 \\
7.5 \\
7.4\end{array}$ & $\begin{array}{l}\text { Much worn. } \\
\text { Not worn. } \\
\text { Do. } \\
\text { Slightly worn. } \\
\text { Not worn. } \\
\text { Slightly worn. } \\
\text { Not worn. } \\
\text { Do. } \\
\text { Slightly worn. }\end{array}$ \\
\hline
\end{tabular}

SOREX ROBORATUS Hollister.

1913. Sorex roboratus Hollister, Smiths. Misc. Coll., vol. 60, No. 24, p. 2, March 13.

The unique type-specimen of this shrew was trapped in the heavy forests of Pinus cembra about 5 miles south of Tapucha, August 7. The species is readily distinguishable in the flesh from Sorex araneus 
borealis, common in the same forest, by its large size, dark color, and large hind foot. In general size it approximates Sorex araneus tetragonurus, but seems not to be closely related to any known form.

\section{MYOTIS PETAX Hollister.}

1912. Myotis petax Hollister, Smiths. Misc. Coll., vol. 60, No. 14, p. 6, November 29 .

No bats were seen in the desert mountains along the Mongolian frontier. The single specimen collected on the trip, the type of this new species, flew into the window of our room in the post station at Kosh-Agatch on the evening of July 30. Bats seem to be rare in the Altai region and only two or three were seen during the trips on the upper Obi and on the long drive from Biisk to the southward. Two bats recorded by Kastschenko ${ }^{1}$ from Cherga, as Vespertilio daubentonii, are doubtless of this species.

\section{CANIS ALTAICUS (Noack).}

1910. Lupus altaicus NoACK, Zool. Anz., vol. 35, p. 465.

There is reason to believe that wolves are fairly plentiful in the Altai; but, strange to say, only one was seen alive by members of our party. The perfect skull of a wolf, found dead near our TcheganBurgazi Pass camp, was preserved. Compared with skulls of Canis lupus from Sweden, this specimen has considerably smaller teeth, a longer, more slender rostrum, and higher, rounded audital bullæ. The differences seem great enough to warrant the separation of the form. Without specimens of the earlier named varieties from Tibet and China for comparison, I use the name altaicus of Noack as unquestionably referring to this animal. We saw a number of wolf skins, including some of small pups, in the trading post at KoshAgatch.

That the wolves destroy many wild sheep, especially during the winter season, is hardly to be doubted. The great numbers of sheep skulls and skeletons found in the mountains show that the game suffers considerably from some cause. Referring to conditions on the Mongolian side of the range, Lyman writes in his journal:

The bottom of the valley is a perfect bone yard. On an average there must be a sheep head for every 200 yards over the 10-mile range of which I am writing. My hunter found a large ram freshly killed by a wolf. Wolves may be the destructive agency. I saw but one in the valley, at a considerable distance. Among the great number of sheep heads in the valley bottom I saw none of very large size.

Demidoff, ${ }^{2}$ in 1897 , while hunting in what seems to be the exact valley of which Lyman writes, had some of his ponies attacked one night by wolves.

The wolf skull from Tchegan-Burgazi Pass is fully adult, with basal suture closed, and is probably a male. It measures: Condylobasal

\footnotetext{
${ }^{1}$ Рез. Алтайской зоол. Эксп. 1898. [Results Altai Zool. Exped. 1898], Vertebrates,
} p. 12, Tomsk, 1899.

3 After Wild Sheep in the Altai and Mongolia, 1900, p. 143. 
length, 244 mm.; zygomatic breadth, 140; mastoid breadth, 82.5; postorbital constriction, 41; interorbital constriction, 45.5 ; rostral breadth over canine, 47; depth of braincase, crest excluded, 64.5 ; palatal depth behind tooth row, 66 ; rostral depth behind canine, 36.1 ; mandible, 190; maxillary tooth row, 107.5; mandibular tooth row, 122.5 ; upper carnassial, 25 by 14.2 ; first upper molar, 16 by 20.5 ; lower carnassial, 27.9 by 10.7 .

VULPES VULPES TARIMENSIS Matschie.

1908. Vulpes tarimensis Matschie, Wiss. Exp. Filchner China und Tibet, vol. 10, 1 teil, p. 166.

The fox is said to be common in the desert mountains in the vicinity of Tchegan-Burgazi Pass. Lyman saw one on the Mongolian side, and we found two skeletons, from which the skulls were saved, on the Siberian slopes. In the trading post at Kosh-Agatch were a number of skins. We purchased a skin from Kalmuks which, from their account, must have been collected near the site of our Tschornia Creek camp, where we obtained the skulls

The form represented is separable from the European Vulpes vulpes by its peculiar color and the large, high audital bullæ. The general color of skins is a yellowish-buff; the face, top of head, and an irregular dorsal stripe tawny-ochraceous; ears black outside. The tail is quite grayish, in marked contrast to the color of the body. The throat, upper breast, and stripe the entire length of ventral side, slate color, mixed with white and buff. This fox is apparently the Vulpes tarimensis of Matschie, based on the flavescens of Blanford ${ }^{1}$ (not? flavescens Gray). Noack has already referred the Altai fox ${ }^{2}$ to Vulpes flavescens Gray. Owing to the general confusion regarding the foxes of central Asia, and to the uncertainty as to the origin of the type of flavescens, it seems best, at present, to follow Matschie and treat the northern fox of the flavescens type as distinct.

The Kalmuks call this fox "dil-koo."

Cranial and dental measurements of Vulpes vulpes tarimensis from the Tchegan-Burgazi Pass.

Condylobasal length.

Zygomatic breadth.

Mastoid breadth....

Interorbital breadth.

Rostral breadth over canines.

Palatal depth behind tooth row

Rostral depth behind canine..

Mandible.

Maxillary tooth row

Mandibular tooth row.

Upper carnassial. .

First upper molar.

Lower carnassial. .

\begin{tabular}{|c|c|}
\hline $\begin{array}{l}175175 . \\
\text { Male ? ad. }\end{array}$ & $\begin{array}{l}175176 . \\
\text { Male ? ad. }\end{array}$ \\
\hline$m m$. & $m m$. \\
\hline $\begin{array}{r}137 \\
73\end{array}$ & $\cdots$ \\
\hline 47.1 & 47.7 \\
\hline $\begin{array}{l}26.3 \\
22.9\end{array}$ & 24. \\
\hline 34. 7 & 34.8 \\
\hline 16. 7 & 16. 8 \\
\hline 106 & 102.5 \\
\hline 65 & 62.5 \\
\hline $13.6 \mathrm{by}{ }^{71.7} 7.8$ & $\begin{array}{r}69.7 \\
8.5 \mathrm{by}\end{array}$ \\
\hline 10 by 12.6 & 4. 5 by 12.5 \\
\hline 15 by 5.9 & 16.4 by 6.5 \\
\hline
\end{tabular}


MUSTELA LYMANI Hollister.

1912. Mustela lymani Holister, Smiths. Misc. Coll., vol. 60, No. 14, p. 5, November 29 .

A stoat was seen running over the rocks at our Tschornia Creek camp, early in the morning, July 1. At the camp in the timber 5 miles south of Tapucha we were fortunate enough to shoot the adult male which was afterwards made the type of this new species. No weasels of the $M$. nivalis group were seen; several skins in full winter pelage, noted in the trading post at Kosh-Agatch, were of the larger species and doubtless lymani. Kastschenko has, however, recorded M. nivalis from the River Komoorlu in his report on the collection made by the Tomsk University expedition of $1901 .^{1}$

MUSTELA (PUTORIUS) LINEIVENTER Hollister.

1913. Mustela lineiventer Hollister, Proc. Biol. Soc. Washington, vol. 26, p. 2, January 18.

Three specimens, all fully adult, from about 9,000 feet in the open alps at Tchegan-Burgazi Pass, July 8, 10, and 23. All were trapped at marmot burrows, and the habits of the animals seem to be much like those of the American black-footed ferret. We saw a number of skins of this polecat in the trading post at Kosh-Agatch, and our Kalmuck and Tartar camp men knew the animal well, using for it the Russian name "kar-yoke'," which doubtless includes the related Mustela eversmanni, an animal not obtained by us. The polecats were perhaps even more infested with fleas than were the ground squirrels and marmots.

MELES AMURENSIS ALTAICUS Kastschenko.

1901. Meles amurensis altaicus Kastschenko, Ann. Mus. Zool. Acad. St.-Pétersbourg, vol. G, p. 613.

We purchased a single skin of this badger. It was collected north of Kosh-Agatsh in the Baskkaous Valley country. No signs of badgers were noted in the border mountain range.

\section{PHODOPUS CREPIDATUS Hollister.}

1912. Phodopus crepidatus Hollister, Smiths. Misc. Coll., vol. 60, No. 14, p. 3, November 29.

Our single night's trapping in the center of the Chuisaya Steppe, July 28 , added 16 of these little hamsters to our collection, and several other specimens not preserved were caught. The burrows are closed by the animals during the day, and there is little evidence of the abundance of the species until the visit to the traps in the morning. A single specimen was caught by Kain, in his hands, on the mountain above Tschornia Creek, at 10,000 feet altitude, July 26. Our per- 
sistent trapping on these higher alplands of the frontier range had failed to produce a specimen of this mouse. The mountain specimen agrees in all details with the series from the Chuisaya Steppe. The wonderfully developed cheek pouches of nearly all the specimens examined were well filled with tiny seeds.

\section{MYOSPALAX MYOSPALAX (Lazmann).}

1773. Mus myospalax Laxmann, Kongl. vet. Acad. Handl., vol. 34, p. 134.

One specimen from the border of alps and forest in the mountains near Tapucha. It would seem from the great number of earth mounds in this vicinity that this species is an abundant one, but our traps were not suited for capturing it, and we had difficulty in obtaining even a single specimen.

\section{MYOPUS MORULUS Hollister.}

1912. Myopus morulus Hollister, Smiths. Misc. Coll., vol. 60, No. 14, p. 1, November 29 .

The unique type-specimen of this lemming was trapped, August 6 , under a $\log$ in the thick nut pine forest 5 miles south of Tapucha, at 6,875 feet altitude. Only a single specimen of the genus has heretofore been recorded from Asia. Middendorff ${ }^{1}$ mentions a skin and skull from the west coast of Okhotsk Sea, which he identified, by a comparison with Liljeborg's colored plate, as the Scandinavian species, M. schisticolor. At the same time Middendorff prophesied that these lemmings would eventually be found to range across the continent, and the capture of a specimen in the Altai goes far toward the fulfillment of his prediction. Middendorff's record is without doubt authentic, and is entitled to more consideration than has hitherto usually been shown it.

EVOTOMYS RUTILUS (Pallas).

1778. Mus rutilus Pallas, Nov. Spec. Quad. Glir. Ord., p. 246.

1874. Evotomys rutilus Coues, Proc. Acad. Nat. Sci. Philadelphia, p. 187.

We found this species abundant in the damp mountain forests near Tapucha, at about 6,900 feet. Sixteen specimens were preserved, collected from August 6 to 11 .

Pallas described his Mus rutilus from the wooded regions and alps east of the Obi River. From this, and the fact that in the same account he refers specimens from the mouth of the Obi to his species, but remarks upon a difference in color, it is reasonable to argue that the "type-locality" of rutilus is near the head of the Obi, close to the Altai, and not at a point near the Arctic coast. Our specimens may, then, be considered as fairly typical. Thomas has recently recorded rutilus from the Syansk Mountains, 100 miles west of Lake Baikal. ${ }^{2}$ 
In color our specimens from the Altai differ conspicuously from a series of $E$. wosnessenskii, from Kamchatka, in the decidedly darker tone of the red, and the much grayer sides. In all the 16 specimens (except one which has the teeth so worn that the enamel pattern is obliterated) the last upper molar has on the inside four salient angles and three re-entrant angles, the posterior loop being deeply cut by an inner re-entrant angle. Ten adults measure, averages and extremes: Head and body, $101 \mathrm{~mm}$. (95-107); tail vertebræ, 34 (30-38); hind foot, without claw, 16.7 (16-17.5).

\section{EVOTOMYS RUFOCANUS (Sundevall).}

1846. Hypudæus rufocanus Sundevall, Öfversigt af Köngl. Vet. Akad. Förhandl., vol. 3 , p. 122.

1897. Evotomys rufocanus BAILey, Proc. Biol. Soc. Washington, vol. 11, p. 122, May 13.

I can not distinguish the six specimens of this mouse collected in the Tapucha forests, August 6 to 11, from Scandinavian examples. A single immature specimen collected at Tchegan-Burgazi Pass is somewhat paler, and has grayer sides and a restricted dorsal stripe; but with the variation in both rufocanus and lataste $i$ in mind is seems best to refer this specimen to the same form as the small series from Tapucha. Thomas has recorded Evotomys rufocanus latastei from a point 100 miles west of Lake Baikal, and remarks that the specimens agree closely with examples from Kamchatka. ${ }^{1}$ Dr. J. A. Allen has kindly lent me a series of seven specimens of his latastei, from Gichiga, northeast Siberia, but as his specimens are all immature my comparisons with latastei are of little consequence. My three immature specimens from Tapucha agree better, however, with immature examples from Norway than with the young of latastei.

The single Tchegan-Burgazi Pass specimen was trapped in open alps at about 9,000 feet elevation. As there are indications of timbered draws within comparatively recent times in the immediate vicinity, it is probable that before the almost complete deforestation of such places the species was more abundant in the frontier range than it is at the present time.

\section{MICROTUS OBSCURUS (Eversmann).}

1841. Hypudaeus obscurus Eversmann, Учен. Записки, Казанскимъ унив., (VIII), I, p. 156. [Mém. sav. univ. Kasan.]

1899. [Microtus arvalis] var. obscurus Trouessart, Cat. Mamm., I, p. 558.

Thirty specimens, from Tchegan-Burgazi Pass and the forests near Tapucha, seem to represent M. obscurus, described by Eversmann from the Altai. The species is allied to Microtus arvalis, but is larger, with a much larger skull, actually smaller teeth, and is much darker and richer colored. In the 30 specimens the true arvalis 
enamel pattern is present in 28. Two have $m^{3}$ abnormal. In one, No. 175333, the last loop has an additional inner reentrant angle posteriorly; and another, No. 175325, has the second outer salient angle of $\mathrm{m}^{3}$ so reduced, and the first inner triangle so lengthened transversely, that it has the appearance of a second loop, much like the anterior loop. It seems quite certain that this is an independent species, and not a race of Microtus arvalis. Poliakoff evidently confused other forms with it. It is uncertain from his account whether he considered the original example the Altai or the Kirghiz Steppe specimen, listed by him. Eversmann in his original description, however, mentions only the Altai and gives measurements of only one specimen.

Measurements of selected adult specimens of Microtus obscurus from the Altai Mountains, Siberia.

\begin{tabular}{|c|c|c|c|c|c|c|c|c|c|c|c|c|}
\hline Locality. & Number. & Sex. & 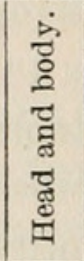 & 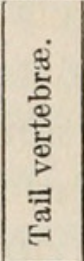 & $\begin{array}{l}\vec{\circ} \\
\text { 。몀 } \\
\text { 总 }\end{array}$ & 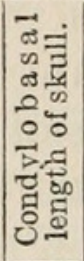 & 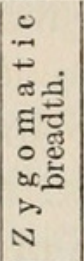 & 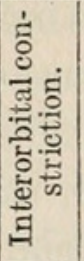 & 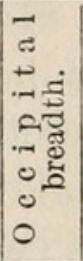 & 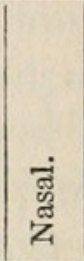 & 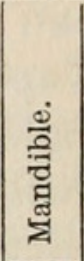 & 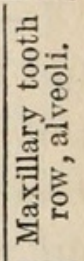 \\
\hline Tchegan-Burgazi Pass. & 175326 & Male. & $\mathrm{mm}_{117}$. & $\mathrm{mm}_{43}$ & $\underset{18}{m m}$. & & $\begin{array}{c}m m . \\
15.4\end{array}$ & $\begin{array}{r}m m . \\
3.5\end{array}$ & $m m$. & $\mathrm{mm}$. & mm. & \\
\hline Do......... & 175322 & Female & 118 & 44 & 17 & & $14^{-7}$ & 3.4 & & 7.2 & 16.3 & \\
\hline Do.. & 175325 & ..do. & 114 & 43 & 17.5 & 26.4 & 14. 2 & 3.3 & 11.4 & 7.4 & 16.5 & \\
\hline Do... & 175237 & .do.. & 117 & 42 & 17 & 26 & 14.4 & 3.5 & 11.5 & 7 & 15. 7 & \\
\hline Tapucha. & 175339 & Male. & 134 & 50 & 18.5 & 27 & 14.6 & 3.5 & 12.4 & 7.7 & 16. $\mathrm{j}$ & \\
\hline Do.. & 175340 & .. do & 126 & 40 & 18 & 26.7 & 14.1 & 3.4 & 11. 7 & 6.9 & 15. 2 & \\
\hline Do. & 175341 & .. d & 124 & 47 & 19 & 27 & 14.5 & 3.5 & 12 & 7.2 & 15. 2 & \\
\hline $\mathrm{D}$ & 175342 & ..d & 119 & 40 & 18 & 25.5 & 14 & 3.4 & 12.2 & 6.9 & 15.5 & \\
\hline D & 175343 & ..do & 127 & 52 & 18 & 26.3 & 14. 2 & 3.2 & 11.6 & 7.5 & 15. 6 & \\
\hline D & 175336 & Female & 120 & 45 & 16.5 & 25.2 & 14. 1 & 3.1 & 11.6 & 7 & 14. 9 & \\
\hline D & 175337 & $\ldots$ do..... & 116 & 41 & 18.5 & 25.6 & 14.4 & 3.5 & 11.5 & 7 & 15. 2 & \\
\hline & 175344 & & 131 & 43 & 18 & & 14.8 & 3.2 & 12.1 & 8 & 16. 2 & \\
\hline & 175345 & .. do & 127 & 50 & 17.5 & 26.2 & 15 & 3.1 & 11.9 & 7. 1 & 16. 2 & \\
\hline & 175346 & $\ldots d$ & 124 & 47 & 17 & 25.5 & 14.6 & 3.4 & 11.9 & 7. 1 & 15.9 & \\
\hline & 175347 & $\ldots \mathrm{d}$ & 118 & 38 & 17 & 25.4 & 14 & 3.5 & 11.5 & 7.4 & 15 & \\
\hline & 175348 & & 124 & 47 & 18 & 26 & 14 & 3.5 & 11.5 & 7 & 15.5 & \\
\hline & 175349 & $\ldots$ do & 125 & 47 & 17 & 26.5 & 14.9 & 3.3 & 12 & 7 & 16. 1 & 6 \\
\hline & 175350 & $d$ & 127 & 44 & 17 & & 14.5 & 3.5 & 12 & 7. 6 & 16.2 & \\
\hline
\end{tabular}

\section{MICROTUS (STENOCRANIUS) EVERSMANNII (Poliakoff).}

1881. Arvicola eversmannii Poliakoff, Annex. Mem. Acad. St.-Pétersbourg, vol. 39 , p. 285.

1901. Microtus (Stenocranius) eversmanni Kastschenko, Ann. Mus. Zool. Acad. St.-Pétersbourg, vol. 6, p. 186.

Eight specimens from the heavy pine forests near Tapucha are referred to this species, described from the Altai. The skins in this series are readily distinguishable from specimens of tianschanicus from the desert ranges to the southward by their richer, darker color, above and below. There seem to be no differences in external measurements nor in the skulls and teeth of the two forms and they probably intergrade. There is a great variation in the size of skull in both forms. Skulls of adults in the Tapucha series range from 25 to $27.5 \mathrm{~mm}$. in condylobasal length. There is a strong tendency 
toward distinctly grooved incisors in several specimens. The name eversmannii of Poliakoff has been misapplied by Büchner to an arvalislike Microtus from further south. This has caused considerable confusion and Mr. Thomas has recently remarked that "judging from Büchner's figure of the skull, M. eversmanni Poliakoff, would seem to be either this [M. arvalis] or a related form, and not a Stenocranius." 1 I believe that Professor Kastschenko, in his paper on the forms of Stenocranius ${ }^{2}$ fixes the true status of eversmannii, as a mountain form of the wide ranging Stenocranius type. In this paper Professor Kastschenko quite properly raises the question if the forms of the subgenus Stenocranius known to him are not possibly all races of one wide ranging species. These forms include M. gregalis (Pallas) not Radde, ${ }^{3}$ not Poliakoff, of eastern Siberia; M. eversmannii (Poliakoff), in the mountains of south-central Siberia; $M$. slowzowii (Poliakoff), of the west Siberian steppes; and $M$. raddei (Poliakoff), of the Transbaikal country. To these Kastschenko adds, in the same paper, three new forms of $M$. slowzowii; lutea from Tomsk, brevicauda from the Yakootsk District, and tridenticulata; the last described as a "variety," not a race, with abnormal enamel pattern, and coming from no special territory.

The Microtus eversmanni of Trouessart, ${ }^{4}$ is likewise not the $M$. eversmannii of Poliakoff, but apparently that of Büchner, and therefore relates to some form of arvalis.

\section{MICROTUS (STENOCRANIUS) TIANSCHANICUS Büchner.}

1889. Microtus tianschanicus Büchner, Wiss. Res. Przewalski Central-Asien Reis. Zool. theil, vol. 1, p. 107.

Thirty-one specimens from the desert mountains near the Mongolian frontier in Tchegan-Burgazi Pass. The skins in this excellent series are uniformly much lighter colored than the lot from the forested mountains near Tapucha, which I have referred to $M$. eversmannii. Aside from the color differences I can detect no characters to separate them. The enormous difference in size of adult skulls of this species is most exceptional but it seems to represent true individual variation. Examination of fresh specimens showed seven plantar tubercles and, in old males, large side glands well forward of the hips. Of two pregnant females examined July 18, one contained 7 embryos, 4 right, 3 left, $12 \mathrm{~mm}$. in diameter; and one 8 large fetuses, 4 right and 4 left. These mice seemed most abundant in the open alplands at from 9,000 to 10,000 feet altitude.

1 Ann. and Mag. Nat. Hist., ser. 8, vol. 9, p. 398, A pril, 1912.

2 Ann. Mus. Zool. Acad. St.-Pétersbourg, vol. C, 1901, pp. 165-206.

3 The Microtus gregalis of Radde and of Poliakoff (not of Pallas), from Transbaikalia, is renamed Microtus poljakowi by Kastschenko in his paper in the Ann. Mus. Acad. St.-Pétersbourg.

Cat. Mamm., vol. 1, p. 599. 
Measurements of selected adult specimens of Microtus (Stenocranius) from the Altai Mountains.

\begin{tabular}{|c|c|c|c|c|c|c|c|c|c|c|c|c|}
\hline Locality. & 苜 & 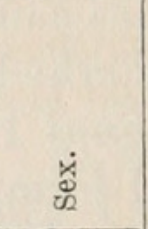 & 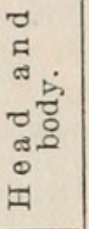 & 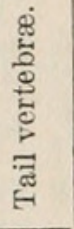 & $\begin{array}{l}\stackrel{\circ}{0} \\
\stackrel{0}{0} \\
\text { : }\end{array}$ & 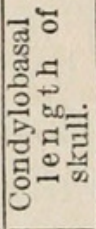 & 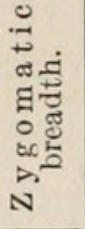 & 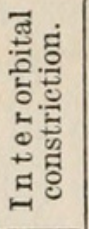 & 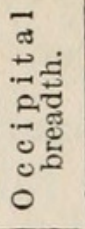 & $\begin{array}{l}\text { Æ̈ } \\
\text { Z }\end{array}$ & 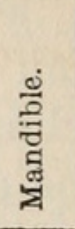 & 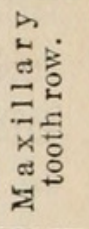 \\
\hline M. eversmanii. & & & & & & & & & & & & \\
\hline Tapucha & 5382 & Male. & 130 & 34 & 17.5 & 27.5 & 13.7 & 2.2 & 11.4 & 7.4 & 16.5 & 5.5 \\
\hline $\begin{array}{l}\mathrm{D} \\
\mathrm{D}\end{array}$ & 3884 & $\begin{array}{l}\text { ‥do. } \\
\text { do. }\end{array}$ & $\begin{array}{l}122 \\
120\end{array}$ & $\begin{array}{l}30 \\
29\end{array}$ & 16.5 & $\begin{array}{l}26.5 \\
24.9\end{array}$ & $\begin{array}{l}13.5 \\
13.2\end{array}$ & 2.1 & 10.4 & $\begin{array}{l}7.4 \\
6.7\end{array}$ & 16.1 & $\begin{array}{l}5.6 \\
5\end{array}$ \\
\hline & 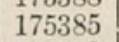 & Female & 121 & 25 & 15.5 & 25.5 & 13 & 2.4 & 10 & 7 & $\begin{array}{l}15 . \\
15\end{array}$ & $\begin{array}{l}5.5 \\
6\end{array}$ \\
\hline & 175389 & $\ldots$ do... & 118 & 26 & 15 & & & 2.4 & 10.3 & 6.7 & & 5.7 \\
\hline M. tianschanicus. & & & & & & & & & & & & \\
\hline $\begin{array}{l}\text { Tehegan } \\
\text { Pass. }\end{array}$ & & & & & & & & & & & & \\
\hline & $\begin{array}{l}175535 \\
175352\end{array}$ & $\begin{array}{l}\text { Male } \\
\text {...do. }\end{array}$ & $\begin{array}{l}116 \\
114\end{array}$ & 33 & 17 & $?$ & 14 & 2.4 & 11.2 & & 16.1 & 6 \\
\hline & 1753 & ....do & $\begin{array}{l}114 \\
123\end{array}$ & 28 & 17.5 & 23.2 & & & 10.5 & $\because 11$ & $\begin{array}{l}10.1 \\
16.2\end{array}$ & \\
\hline & 1 & & 12 & 96 & 16 & 2 & 13. & 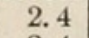 & & & 16.1 & 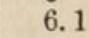 \\
\hline & & & 115 & 35 & 16 & 27 & & 2.4 & 11 & 6.5 & 16 & 6 \\
\hline & $\begin{array}{l}1753 \mathrm{c} \\
1753 \mathrm{~s}\end{array}$ & Fem & 112 & 25 & 14 & 23.8 & 12. & 2.5 & io & 6.5 & $\begin{array}{l}10.1 \\
15.1\end{array}$ & $\begin{array}{l}0 \\
5 .\end{array}$ \\
\hline & 17 & $\ldots \mathrm{dc}$ & 119 & 23 & 16 & & 12 & 2.4 & 10.2 & 6.4 & 15.4 & 5. \\
\hline & & & & 25 & 16 & 24.5 & & 2. & & 6.4 & & \\
\hline $\begin{array}{l}\text { Do. } \\
\text { Do. }\end{array}$ & $\begin{array}{l}175372 \\
175376\end{array}$ & $\begin{array}{l}\text {..do.. } \\
\text { ‥do.. }\end{array}$ & 115 & 29 & $\begin{array}{l}15.5 \\
15.5\end{array}$ & 25 & $\begin{array}{l}13 \\
12.9\end{array}$ & $\begin{array}{l}2.4 \\
2.5\end{array}$ & $\begin{array}{l}100.1 \\
10.1\end{array}$ & $\begin{array}{l}6.6 \\
6.8\end{array}$ & $\begin{array}{l}15.3 \\
15.6\end{array}$ & $\begin{array}{l}6.5 \\
5.5\end{array}$ \\
\hline & & & & & & & & & & & & \\
\hline
\end{tabular}

ALTICOLA (PLATYCRANIUS) STRELZOVI (Kastschenko).

1899. Microtus strelzovi Kastschenko, Рез. Алтайской Зоол. Экег. 1898. [Results Altai Zool. Exp.] Tomsk, p. 50, pl. 2, figs. 2, 3.

1901. Microtus (Platycranius) strelzowi Kastschenko, Ann. Mus. Zool. Acad. Sci.

St.-Pétersbourg, vol. 6, p. 201.

Seventy-two specimens from the frontier range in the TcheganBurgazi Pass, July 1-26. This mouse is by far the most abundant mammal in the rocky parts of the desert mountains. At least a hundred specimens were caught in addition to the number preserved. Our experience with the species exactly agrees with Kastschenko's account of its local habitat, and we caught the animal only among the loose rocks. So closely is it confined to rocky cliff sides that, although exceedingly abundant in such places, traps set only a few feet out in the grassy creek bottoms, or in the alps above the rocks, almost invariably failed to catch specimens. The fully adult examples, when freshly caught and in full coat, are strikingly handsome mammals. Most of our specimens were taken at about 8,500 feet elevation, and although a few were captured up to a thousand feet higher, the lower cliffs near the stream beds seemed to be the normal home. At Tapucha we did not catch this mouse, doubtless because we trapped almost entirely in the forest and alps. The type-locality is Lake Tenga, only about 25 versts south of Tapucha, but at a much lower elevation and in a much more open country.

The subgenus Platycranius, described by Kastschenko as a subgenus of Microtus, is clearly an aberrant Alticola, as surmised by Miller. ${ }^{1}$ The palate, enamel pattern, mammary and plantar tubercle 
formulas are as in Alticola, and the two distinguishing characters, the large ears and peculiarly flattened skull, seem best considered as subgeneric.

Measurements of selected adult specimens of Alticola (Platycranius) strelzovi from the Tchegan-Burgazi Pass, Altai Mountains, Siberia.

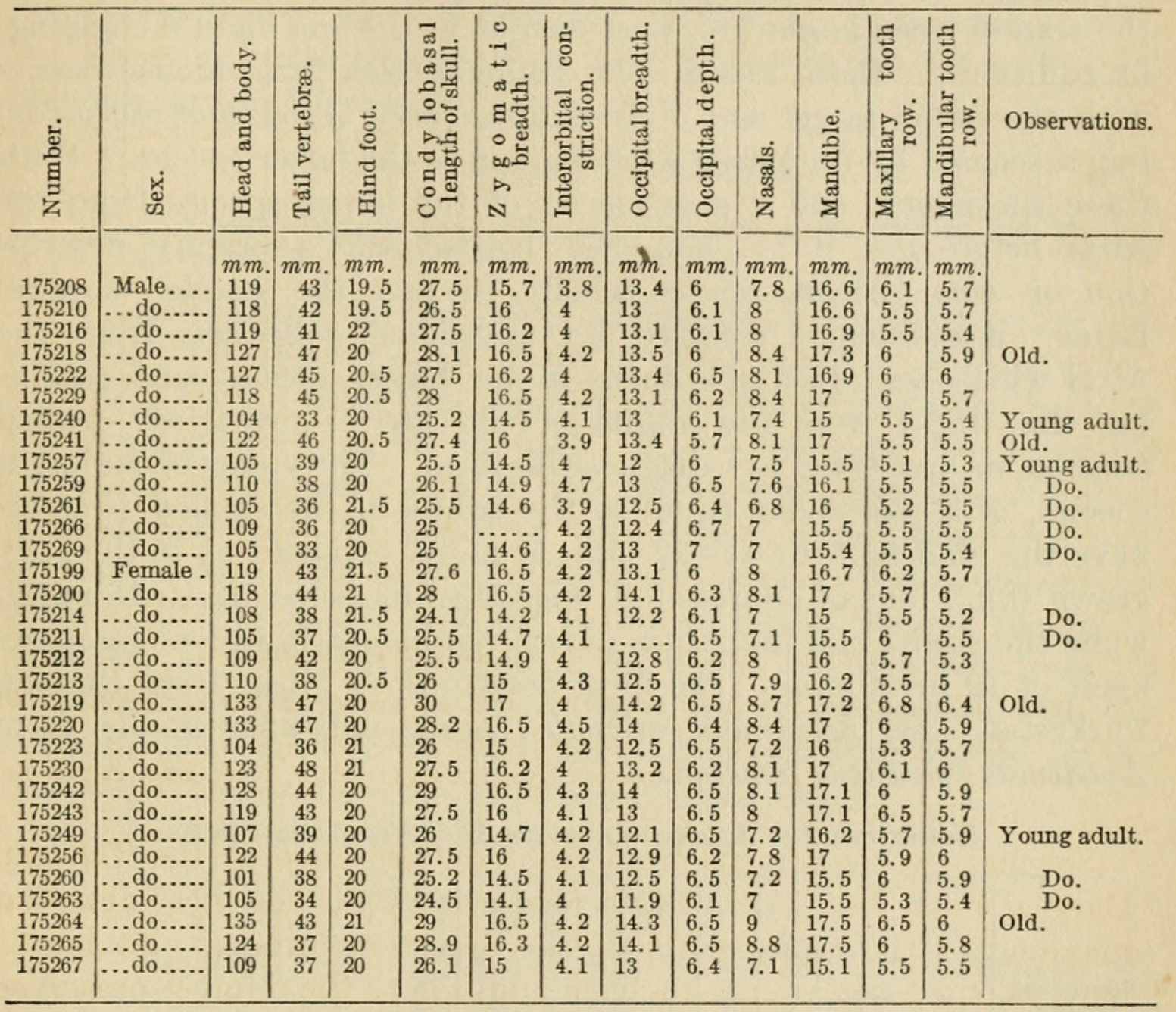

APODEMUS NIGRITALUS Hollister.

1913. Apodemus nigritalus Hollister, Smiths. Misc. Coll., vol. 60, No. 24, p. 1, March 13.

Ten specimens from the heavy forests of Pinus cembra near Tapucha, August 6-11. These were trapped in small grassy openings in the woods, usually under logs or bushes. This species is a member of the speciosus group, and is rather nearly related to Apodemus peninsulæ of Korea and northern China. It is readily distinguishable from the smaller Apodemus sylvaticus tscherga, which occurs in the same forests, by its much larger size, more reddish coloration, the heavy supraorbital beads on the skull, and the presence in females of eight mammæ instead of six.

\section{APODEMUS SYLVATICUS TSCHERGA (Kastschenko).}

1899. Mus tзcherga Kastschenko, Рез. Алтайской Зоол. Эксп. 1898. [Results Altai Zool. Exp.], Tomsk, p. 46.

1910. Mus sylvaticus tscherga Kastschenko, Ann. Mus. Zool. Acad. St.-Pétersbourg, vol. 15, No. 3, p. 283.

1912. A podemus tscherga Thomas, Ann. and Mag. Nat. Hist., ser. 8, vol. 9, p. 397, April. 
Three specimens. Two of these were trapped under thorn bushes on the dry, semi-desert hills near Ust-Inya, at 3,850 feet, June 24, and one was captured at the Tapucha camp in heavy forest bordering open alps at 6,875 feet, August 8. The species was evidently a common one at Ust-Inya, as several examples, either ruined by the trap or very immature, were caught in the one night's trapping, in addition to those saved. At Tapucha this little mouse occurs with the much larger and differently colored Apodemus nigritalus, but it seemed by no means as abundant as the latter species. With these specimens, and a good series of the larger species from the Altai before me, it is plain that Kastschenko's original description of Mus tscherga relates wholly to this, the smaller, species. Later $^{1}$ Kastschenko received an additional collection from the Altai which contained specimens of the larger species, and assuming that these were the adults of the species previously named tscherga, he proceeded to rediagnose his form. The young of the larger species, of a size about equal to the adults of the smaller tscherga, have the hind foot always $22 \mathrm{~mm}$. or more, or about as in the fully grown (hind foot of adults of $A$. nigritalus measures 22 to $25 \mathrm{~mm}$.), while the adults and immature of tscherga have a hind foot measurement of 19 or $20 \mathrm{~mm}$. The form described by Miller from Russian Turkestan $^{2}$ as Apodemus microtis seems indistinguishable from Apodemus sylvaticus tscherga.

Measurements of Apodemus from the Altai Mountains, Siberia.

\begin{tabular}{|c|c|c|c|c|c|c|c|c|c|c|c|c|c|c|}
\hline $\begin{array}{l}\text { Species and } \\
\text { locality. }\end{array}$ & $\begin{array}{l}\text { 㟧 } \\
\text { 竞 } \\
\text { Z }\end{array}$ & Sex. & 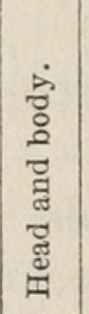 & 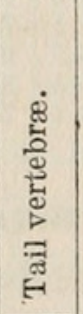 & $\begin{array}{l}\dot{\overrightarrow{0}} \\
\stackrel{0}{0} \\
\dot{\Xi} \\
\dot{H}\end{array}$ & 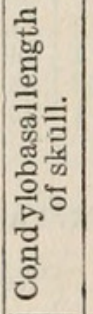 & 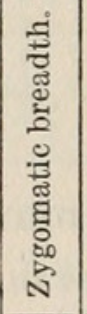 & 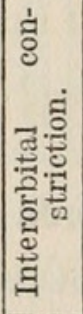 & 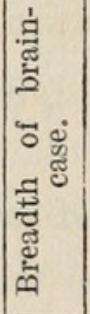 & 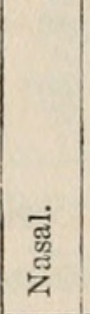 & 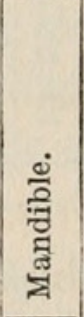 & 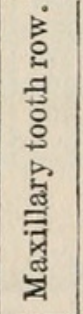 & 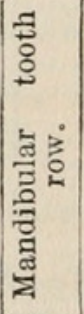 & Observations. \\
\hline \multicolumn{15}{|l|}{$\begin{array}{l}\text { A. sylvaticus } \\
\text { tscherga. }\end{array}$} \\
\hline Ust-Inya.... & 175172 & Male.. & $\begin{array}{r}m m_{9} \\
94\end{array}$ & $\begin{array}{r}m m . \\
77\end{array}$ & $\begin{array}{r}m m \\
20\end{array}$ & $\begin{array}{l}m m . \\
22.8\end{array}$ & $\begin{array}{l}m m . \\
11.5\end{array}$ & $\begin{array}{r}m m .8 \\
3.8\end{array}$ & $\begin{array}{l}m m . \\
11.2\end{array}$ & $\begin{array}{c}m m \\
9\end{array}$ & $\begin{array}{l}m m . \\
13.1\end{array}$ & $\begin{array}{r}m m \\
3.5\end{array}$ & $\begin{array}{r}m m . \\
3.0\end{array}$ & Teeth moder \\
\hline Do.. & 175173 & Female & 97 & 72 & 19 & 22.4 & 12.5 & 3.6 & 10.9 & 10 & 14 & 3.6 & 3.6 & Teeth much \\
\hline $\begin{array}{l}\text { Tapucha..... } \\
\text { A.nigritalus. }\end{array}$ & 175174 & Male. & 83 & 75 & 19 & 21.2 & 11.9 & 3.9 & 11.2 & 8.6 & 13 & 3.6 & 3.8 & $\begin{array}{l}\text { Teeth slightly } \\
\text { worn. }\end{array}$ \\
\hline $\begin{array}{r}\text { Tapucha. } \\
\text { Do... } \\
\text { Do... }\end{array}$ & $\begin{array}{l}175162 \\
175164 \\
175167\end{array}$ & $\begin{array}{l}\ldots \text { do.... } \\
\ldots . \text { do.... } \\
\ldots . \text { do.... }\end{array}$ & $\begin{array}{l}102 \\
122 \\
109\end{array}$ & $\begin{array}{r}96 \\
102 \\
\ldots \ldots\end{array}$ & $\begin{array}{l}23 \\
25 \\
23\end{array}$ & $\begin{array}{l}25 \\
27.5 \\
25.6\end{array}$ & $\begin{array}{l}13.2 \\
14.8 \\
14\end{array}$ & $\begin{array}{l}4.1 \\
4.3 \\
4.5\end{array}$ & $\begin{array}{l}12.4 \\
12.5 \\
12.3\end{array}$ & $\begin{array}{l}10.2 \\
11.5 \\
10.6\end{array}$ & $\begin{array}{l}15.5 \\
17 \\
16.1\end{array}$ & $\begin{array}{l}3.7 \\
4.1 \\
3.9\end{array}$ & $\begin{array}{l}3.7 \\
4 \\
3.9\end{array}$ & $\begin{array}{l}\text { Do. } \\
\text { Type. } \\
\text { Teeth much }\end{array}$ \\
\hline Do. & 175169 & do & 100 & 84 & 22 & 25.1 & 13 & 4.2 & 12.1 & 10 & 15.4 & 3.7 & 3.9 & Teeth slightly \\
\hline $\begin{array}{l}\text { Do..... } \\
\text { Do..... } \\
\text { Do..... } \\
\text { Do.... }\end{array}$ & $\begin{array}{l}175170 \\
175163 \\
175165 \\
175166\end{array}$ & $\begin{array}{l}\text {...do.... } \\
\text { Female } \\
\ldots . . \text { do..... } \\
\ldots \text {..do.... }\end{array}$ & $\begin{array}{r}108 \\
106 \\
102 \\
97\end{array}$ & $\begin{array}{l}87 \\
88 \\
92 \\
87\end{array}$ & \begin{tabular}{l|}
25 \\
23 \\
22 \\
23
\end{tabular} & \begin{tabular}{l|}
25 \\
24.5 \\
24.1 \\
23.6
\end{tabular} & $\begin{array}{l}13 \\
13.4 \\
13.1 \\
13\end{array}$ & \begin{tabular}{|l}
4.1 \\
4.1 \\
4.2 \\
4
\end{tabular} & $\begin{array}{l}12.1 \\
12 \\
12 \\
12\end{array}$ & $\begin{array}{l}9.5 \\
9.7 \\
9.3 \\
9.5\end{array}$ & \begin{tabular}{l|}
16.5 \\
15.5 \\
15.7 \\
15
\end{tabular} & $\begin{array}{l}4 \\
4 \\
3.6 \\
4\end{array}$ & $\begin{array}{l}4 \\
3.9 \\
3.7 \\
4\end{array}$ & $\begin{array}{l}\text { Do. } \\
\text { Do. } \\
\text { Do. } \\
\text { Teeth un }\end{array}$ \\
\hline $\begin{array}{l}\text { Do... } \\
\text { Do... }\end{array}$ & $\begin{array}{l}175168 \\
175171\end{array}$ & $\begin{array}{l}\ldots \text { do... } \\
\ldots \text {..do... }\end{array}$ & $\begin{array}{r}87 \\
113\end{array}$ & $\begin{array}{r}74 \\
101\end{array}$ & $\begin{array}{l}23 \\
23\end{array}$ & $\begin{array}{l}22 \\
26.1\end{array}$ & $\begin{array}{l}12.6 \\
13.5\end{array}$ & $\begin{array}{l}3.9 \\
4: 1\end{array}$ & $\begin{array}{l}12 \\
12.1\end{array}$ & $\begin{array}{r}8.6 \\
11.1\end{array}$ & \begin{tabular}{l|}
14.2 \\
17
\end{tabular} & $\begin{array}{l}4 \\
4.1\end{array}$ & $\begin{array}{l}4 \\
3.0\end{array}$ & $\begin{array}{l}\text { worn. } \\
\text { Do. } \\
\text { Teeth much } \\
\text { worn. }\end{array}$ \\
\hline
\end{tabular}




\section{SICISTA NAPEA Hollister.}

1912. Sicista napaea Hollister, Smiths. Misc. Coll., vol. 60, No. 14, p. 2, November 29.

A single specimen of this jumping mouse was trapped in the damp pine forest 5 miles south of Tapucha, August 6. It was caught in a densely grown part of the woods near the border of extensive open alplands, at 6,875 feet elevation.

\section{ALLACTAGA GRISESCENS Hollister.}

1912. Allactaga grisescens Holdister, Smiths. Misc. Coll., vol. 60, No. 14, p. 2, November 29.

Two specimens from the center of the Chuisaya Steppe, near the banks of the upper Chuya River, 8 miles south of Kosh-Agatch, July 28. One of these was trapped; the other was shot by Kain on the open steppe just before dark. A few burrows, too large for Phodopus, which were seen on the steppe were doubtless the dens of these jerboas. As stated in the original description, this new species seems related only to Allactaga mongolica and its subspecies longior. It is possibly confined to the Chuisaya Steppe, the fauna of which is decidedly Mongolian, as might be expected from its isolation from the great Siberian plains and its connection with the northern extensions of the Gobi, the Kobdo and Suok Plains, by the Tarkuta, Tchegan-Burgazi, and Bain-Chagan Passes.

The Kalmuks call this jerboa "yel'-mahn."

\section{MARMOTA CENTRALIS (Thomas).}

1909. Arctomys centralis Thomas, Ann. and Mag. Nat. Hist., ser. 8, vol. 3, p. 260, March.

Four skins and skulls and four odd skulls from the TcheganBurgazi Pass. The skin of this marmot is one of the chief articles of trade from the natives. We saw great bales, containing hundreds of skins each, in the trading post at Kosh-Agatch, and the trader informed us that he had only a short time before sent a large shipment to Biisk. The animal is known to all the natives by the Russian name "su-rock"."

The Altai marmot was first separated by Brandt, but his name for the animal appears to be a nomen nudum, in every instance of its use, down to Kastschenko's paper on the Results of the Tomsk Altai Expedition in 1899. In the meantime the name has become valid as a synonym of Marmota bobak in Trouessart's Catalogue of Mammals, 1897. The Marmota centralis of Thomas, from the northern Tian-Schan seems to be identical with the Altai form, however, so the species is provided with a name. The relationships seem close with the Transbaikal Marmota sibirica, of which centralis will doubtless prove to be a subspecies. 


\section{CITELLUS EVERSMANNI (Brandt).}

1841. Spermophilus eversmanni Brandt, Bull. Sci. Acad. St.-Pétersbourg, vol. 9, p. 43.

1903. Citellus eversmannii Allen, Bull. Amer. Mus. Nat. Hist., vol. 19, p. 142 , March 31.

We first saw this spermophile at Cherga, two days' journey south from Biisk. Two young specimens were killed in the house where we spent the night at that place. The people called them rats and seemed little surprised to find them in the buildings. The next day, June 20, we noted many of the animals between Shebalina and Tapucha. Every grassy flat was inhabited by them, and though a cold rain was falling the spermophiles paid no attention to it and were apparently all out feeding. Ground squirrels were abundant in the Alpine flats between Tapucha and Ongudai, but only a few were seen beyond Ongudai until we reached the desert frontier range. The animals were exceedingly abundant about, our Tchegan-Burgazi camp, and during our stay in this neighborhood we collected a series of 50 specimens. During the early part of July most of the animals, and especially the nursing females, were in a faded and ragged state of pelage, but before the end of the month we secured many specimens in the bright, fresh coat. The great difference in age between numerous young examples indicates a long breeding season. We found spermophiles in all sorts of places, and the burrows were placed both in rocky cliffs and far out in the open alplands. In addition to innumerable fleas, the spermophiles are terribly infested with botts (Cuterebra, sp.) and it is rare to obtain an example without half a dozen or more in some part of the skin.

Our Tartar and Kalmuk camp men called this species "you-mahrŭnk'.'

\section{EUTAMIAS ASIATICUS ALTAICUS Hollister.}

1912. Eutamias asiaticus altaicus Hollister, Proc. Biol. Soc. Washington, vol. 25, p. 183, December 24.

A single chipmunk was seen at Chibit, June 26. Later, in the heavier forested region south of Tapucha, we found the species abundant and collected a series of 12 specimens. Not one was seen beyond a point about 15 miles south of Tapucha. The animal is remarkably quiet for a chipmunk and might readily be passed many times unobserved. Only rarely did we hear a low "chip" note.

\section{OCHOTONA NITIDA Hollister.}

1912. Ochotona nitida Hollister, Smiths. Misc. Coll., vol. 60, No. 14, p. 4, November 29 .

Thirty-one specimens; 17 from near the Mongolian border in Tchegan-Burgazi Pass, and 14 from the Tapucha camp. Along the upper Chuya River, in Tchegan-Burgazi Pass, we found pikas chiefly in the lower rocky cliffs along the main river and its tributary, Tschornia Creek, at about 8,500 feet elevation. The call note is decidedly different from that of the American pikas, and was not at first recog- 
nized. It is much more like the high pitched note of some small bird and lacks all the nasal tone so characteristic of our species. The old animals, from July 1 to 25 , were chiefly in the left-over winter pelage, or in a ragged state of molt. The young were already nearly grown, some of them molting the post-juvenal pelage and renewing into the brown fall coat of the adult. Numbers were caught in rat traps baited with rolled oats, a method I have never found at all successful with various American species.

In the heavily forested mountains near Tapucha we found pikas on the rocky tops, and even in dry rocky creek beds far below timberline. In these latter localities they seemed entirely out of place to us, but were nevertheless fully at home. The specimens taken here from August 7 to 10 are in full fresh fall coat. Our Tartar and Kalmuk camp men called the pika "seen-ă-stăft'."

I believe that true $O$. alpina, from which I have separated this species, will be found to inhabit the Bia-Altai, the region north of Lake Teletzkoi, and between the Bia and the Katun Rivers. There is a specimen of alpina in the United States National Museum labeled "Barnaul."

Measurements of Ochotona nitida from the Altai Mountains, Siberia.

\begin{tabular}{|c|c|c|c|c|c|c|c|c|c|c|c|}
\hline Locality. & 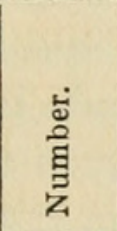 & Sex. & 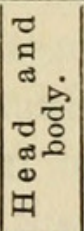 & 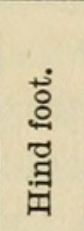 & 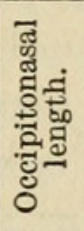 & 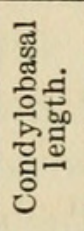 & 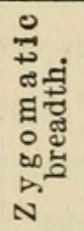 & 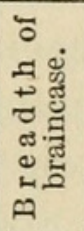 & 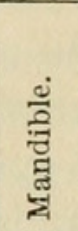 & 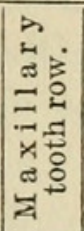 & Observations. \\
\hline $\begin{array}{l}\text { Tchegan-Burgazi } \\
\text { Pass. }\end{array}$ & 175391 & Male & $\begin{array}{c}m m \\
207\end{array}$ & $\begin{array}{l}m m . \\
30.5\end{array}$ & $\begin{array}{l}m m .2 \\
47.2\end{array}$ & $\begin{array}{l}m m .7 \\
44.7\end{array}$ & $\begin{array}{l}m m . \\
23.5\end{array}$ & $\begin{array}{l}m m . \\
20\end{array}$ & $\begin{array}{l}m m . \\
31.1\end{array}$ & $\begin{array}{l}m m \\
8.9\end{array}$ & \\
\hline Do... & $\begin{array}{l}175393 \\
175397\end{array}$ & ...do. do. & 190 & $\begin{array}{l}29 \\
29,5\end{array}$ & 43.8 & $\begin{array}{l}41.6 \\
42.9\end{array}$ & 22.4 & 18.6 & 30.2 & 8.5 & Young adult. \\
\hline Do... & 175400 & ...do..... & $\begin{array}{l}195 \\
188\end{array}$ & $\begin{array}{l}29.5 \\
29\end{array}$ & $\begin{array}{l}45.5 \\
44\end{array}$ & $\begin{array}{l}42.9 \\
41\end{array}$ & $\begin{array}{l}22.1 \\
23\end{array}$ & $\begin{array}{l}19 \\
18.1\end{array}$ & $\begin{array}{l}30 \\
29\end{array}$ & $\begin{array}{l}8.1 \\
8.2\end{array}$ & Do. \\
\hline Do. & 175403 & $\ldots$ do.... & 197 & 30 & 46.5 & 44.1 & 22.5 & 19 & 30.5 & 8.5 & Do. \\
\hline Do. & 175390 & Female. & 208 & 30 & 47.6 & 43.6 & 22.5 & 20.5 & 30.5 & 8.5 & Type. \\
\hline Do. & 175392 & ...do.... & 206 & 30 & 44.5 & 43.5 & 22.7 & 19 & 30 & 8 & \\
\hline Do.. & 175394 & ...do... & 182 & 30 & 44 & 41 & 21.5 & 19.1 & 29.1 & 8.1 & \\
\hline Do... & 175405 & ...do. & 220 & 28 & 44.2 & 42.5 & 22.6 & 19.5 & 30.5 & 8.5 & \\
\hline Tapucha. & 175406 & Male.. & 185 & 30 & 45.6 & 42.4 & 23 & 19 & 30.4 & 8 & \\
\hline Do. & 175407 & ...do.... & 200 & 30.5 & 48.5 & 45 & 23 & 19.4 & 31 & 8 & old. \\
\hline Do. & 175408 & ...do. & 189 & 30 & 47.9 & 44.5 & 22 & 19.4 & 30 & 8.5 & \\
\hline Do. & 175412 & $\ldots$ do & 202 & 30 & 44.6 & 42.6 & 22.1 & 18 & 30.4 & 8 & \\
\hline Do. & 175413 & .. do. & 180 & 28 & 42 & 39.5 & 21.1 & 17.1 & 27.5 & 7.8 & Young adult. \\
\hline Do. & 175415 & $\ldots d$ & 218 & 32 & 46.5 & 45 & 24.5 & 19.7 & 31.1 & 8.7 & Old. \\
\hline Do. & 175418 & .. do. & 185 & 28 & 45 & 42.5 & 23.5 & 19.7 & 28.8 & 8.2 & \\
\hline Do. & 175419 & $\ldots$ do. & 180 & 29 & 44.1 & 41 & 22 & 19 & 29 & 8.1 & \\
\hline Do. & 175409 & Female. & 189 & 29 & 43 & 41.1 & 21.9 & 18.7 & 29.4 & 8 & Young adult. \\
\hline & 175410 & ... do.... & 202 & 30.5 & 47.8 & 44.4 & 24.5 & 19.5 & 31.2 & 8.1 & \\
\hline Do. & 175411 & ...do.... & 191 & 28 & 44.5 & 41.2 & 22 & 18 & 28.2 & 8.1 & \\
\hline & 175414 & $\ldots d$ & 205 & 30 & 41.8 & 42.7 & 23 & 19.2 & 30 & 8 & \\
\hline Do. & 175416 & $\ldots$ do.... & 191 & 29 & 46 & 42 & 23 & 19 & 30 & 8.1 & \\
\hline Do.... & 175417 & ...do.... & 191 & 28 & 43 & 40.8 & 21.1 & 18.5 & 29 & 7.9 & Do. \\
\hline
\end{tabular}

LEPUS LUGUBRIS Kastschenko.

1899. Lepus lugubris Kastschenко, Рез. Алтайской Зоол. Эксп. 1898 [Results Altai Zool. Exp.], Tomsk, p. 57, pl. 2, fig. 4.

1900. Lepus timidus altaicus Barretr-Hamilton, Proc. Zool. Soc. London, p. 90, February 6. (Not Lepus altaicus Waterhouse, Mammalia, II, p. 45, 1848, in synonymy of Lepus hybridus Desmarest.)

We met with this hare only in the Tapucha forests where, with difficulty, we secured three specimens; a skin and skull of a male in 
juvenal pelage, head and skull of a male in post-juvenal pelage, and an odd skull of an adult. These specimens are nearly topotypes of lugubris, which was described primarily from a specimen taken at Ongudai. Neither of the skins has the outer side of the ear entirely black, as described of the species by Kastschenko and by BarrettHamilton; this may possibly be due to their immaturity. The adult skull, compared with skulls of timidus, agrees perfectly with the account given by Kastschenko. It is evident from the differences in the age of the two young animals secured that this hare breeds at least twice during the season.

\section{LEPUS ZAISANICUS Satunin.}

1907. Lepus zaisanicus Satunin, Ann. Mus. Zool. St.-Pétersbourg, vol. 11 (1906), p. 161.

Four hares from Tchegan-Burgazi Pass, near the Mongolian border, differ from all other Asiatic species, and agree very well with the color description and measurements of Lepus zaisanicus, and are therefore provisionally referred to that species. The upper incisors of these specimens, both juvenal and adult, present a remarkable appearance in being projected far forward. The skull of zaisanicus was not described by Satunin, and it is impossible without direct comparison to judge if these specimens actually represent his species, but from the external characters and on geographical grounds it seems most probable. The specimens were collected from July 9 to 25 , on the high open alplands above Tschornia Creek, at from 8,700 to 10,000 feet elevation. Hares were by no means abundant in these mountains and comparatively few were seen. Lyman reported seeing a considerable number while sheep hunting on the Mongolian side of the range.

\section{LEPUS QUERCERUS Hollister.}

1912. Lepus quercerus Holisster, Proc. Biol. Soc. Washington, vol. 25, p. 182; December 24.

The hares of the "tolai group" collected on the Chuisaya Steppe, near Kosh-Agatch, differ conspicuously from all the previously described species from northern Mongolia and Siberia, and are specifically distinct from the hares of the border mountains to the southward, which I have referred to Lepus zaisanicus Satunin. Hares are much more numerous on the desert steppe than in the higher mountains, and six were killed by members of our party during the 24 hours collecting in the center of the plain. Four specimens were preserved. It is not at all unlikely that this species is confined to the Chuisaya Steppe, as we failed to find it in the desert mountains to the southward, and the heavy forest on the north must prove an effective barrier to such a desert species. The Kalmuks call this hare "ko-yun'." 


\section{CAPREOLUS PYGARGUS (Pallas).}

1771. Cervus pygargus Pallas, Reise prov. Russ. Reichs, vol. 1, p. 453.

1843. Capreolus pygargus Gray, List mamm. British Mus., p. 176.

Roedeer are fairly abundant in the timbered parts of the Altai. We saw many horns, attached to small parts of the frontals, in the trading posts, and at Kosh-Agatch the trader had a great many pairs. He told us that the animal is very abundant at times north of KoshAgatch, and in the winter many come down in the low foothills near town. It is then that most of these heads are taken. We obtained five representative sets of antlers from this place. In the Tapucha forest in August, in the early morning or late evening, we frequently heard roebucks barking. Lyman's journal, written at this place, contains the following notes:

The roedeer near the pass to the south of Tapucha appear to spend the day in the thick cover in the valleys. Here they are protected by the rank grass and the bushes. In the late evening they come up on the high rocky outcrops which rise on both sides of the valley bottom. I saw two in the timber, probably females, and one on the hillside. The calling of the males, which I heard several times, is much like the barking of an angry dog. At first I thought there were very few roedeer in this region, but later I came to believe they were fairly plenty. If the weather be fine, it should not be difficult to get a shot if one concealed oneself in these outcrops in the evening.

Two varieties of the Siberian roedeer have been described by Méhely. ${ }^{1}$ A slender horned lowland form trom Tomsk, Ekaterinburg, and other plains localities he calls Capreolus pygargus leptocerus, and a heavy horned upland form from Minusinsk he calls $C . p$. pachycerus. These subspecies are based on hunters' frontals and antlers, such as are collected and traded by natives throughout the southern Siberian mountains in great numbers. Kastschenko ${ }^{2}$ states that no roedeer are known on the Siberian plains, and he believes that Méhely's horns aro from unknown localities. He states further:

Therc are no roedeer near Tomsk, which Méhely repeatedly indicated as one source of his material; but by sportsmen and by commerce many horns are brought to Tomsk from the Altai. Probably the horns were obtained by Count Zichy in Tomsk.

In an earlier paper, Kastschenko ${ }^{3}$ has shown the immense variation exhibited by roedeer antlers from the Altai. Our observations in the trading posts, and the series of antlers brought back by us, agree well with his remarks; and these names for races of roedeer, based on antlers of unknown origin, may both be placed in the synonymy of pygargus.

\section{OVIS AMMON (Linnæus).}

1758. Capra ammon Linnæus, Syst. Nat., ed. 10, vol. 1, p. 70.

1777. Ovis ammon Erxleben, Syst. Regn. Anim., vol. 1, p. 250.

After crossing the Chuisaya Steppe, the second day south from Kosh-Agatch, we saw weathered horns, and an occasional skull, of

1 Dritte asiatische Forschungsreise des Grafen Eugen Zichy, vol. 2, Zoolog. Ergeb. I, Säugethiere, 1901, p. 18 , pl. 4 .

2 Ann. Mus. Zool. Acad. St.-Pétersbourg, vol. 7, 1902, pp. 294-296.

3 Results Altai Zool. Exp., 1898, Tomsk, 1899, pp. 25-40, pls. 3, 4. 
the wild sheep in the valley of the upper Chuya; and as we neared the Mongolian line these relics of the former occurrence of sheep, to the north of their present distribution, became more common. In the bed of Tschornia Creek were numbers of old weathered horns and parts of skulls, and though sheep do not range in these hills at the present time, in summer at least, they must have commonly grazed here not many years ago. In the border range, at the head of Tschornia Creek, Kain found signs of sheep which he believed had been made that same spring, and also much evidence that bands winter on those slopes. Several heads and parts of carcasses, probably of animals destroyed by wolves, were comparatively recent kills. During the summer, of late years, most of the sheep range on Mongolian territory. We were assured by all the natives that no sheep are known in the country north of Kosh-Agatch. We saw numbers of skins in the trading post, all of which were said to come from the neighborhood of Tchegan-Burgazi Pass.

Lyman collected four fine rams on the Mongolian slopes, in the Taylüke Valley, not far from Tarkuta Pass, July 6 to 20. Thomas ${ }^{1}$ has fixed the type-locality of Ovis ammon as the upper Irtisch River, Siberia, so our specimens may be assumed to be fairly typical. These four summer skins are almost free of the old pelage and are renewing the coat. The hair is very short, mixed white and brown, and the general color varies greatly, from quite white to brown with the rump patch not at all conspicuous. Among the winter skins seen in Kosh-Agatch, all said to come from Tchegan-Burgazi Pass, the range of color was equally great, and we purchased examples of the extremes. One is rather light brown with grayish neck and shoulders, and the underside of body pure white. The other is very dark blackish-brown, almost black, with whitish dorsal stripe, broadly pure white on withers and mixed with brown hairs on neck and lower back. All the winter skins show the large white rump patch in sharp contrast to the color of back and hips. The horns of our four rams are good average size, by no means "record heads," and exhibit the normal circumference and spread. The skulls and horns measure as follows:

\begin{tabular}{|c|c|c|c|c|}
\hline Skulls of Ovis ammon. & 175180 & 175181 & 175182 & 175183 \\
\hline 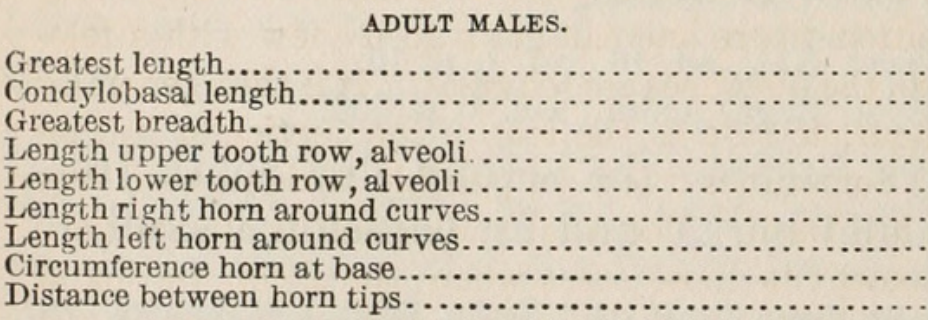 & $\begin{array}{r}m m \\
367 \\
357 \\
193 \\
98 \\
102 \\
1,205 \\
1,155 \\
470 \\
875\end{array}$ & $\begin{array}{r}m m_{1} \\
371 \\
362 \\
195 \\
99 \\
105 \\
1,096 \\
1,185 \\
453 \\
673\end{array}$ & $\begin{array}{r}m m_{3} \\
347 \\
194 \\
98 \\
104 \\
1,146 \\
1,153 \\
475 \\
740\end{array}$ & $\begin{array}{r}389 \\
359 \\
207 \\
100 \\
103 \\
1,278 \\
1,204 \\
485 \\
780\end{array}$ \\
\hline
\end{tabular}


Heads of greater size may be had if one is eager for extreme measurements. Two sportsmen, besides our party, visited the range of this sheep earlier in the season of 1912, and obtained large heads. The horns of one of these heads, which I afterwards examined in the establishment of Rowland Ward, London, measured over 60 inches (1524 mm.) around the curve, and is, I was told, the largest sheep head received at Ward's in several years.

The following extract, taken from Lyman's manuscript journal of his sheep hunt across the Mongolian border, begins with July 1, the day he left our camp in Tchegan-Burgazi Pass. It is interesting, not only as an account of this wonderful sheep, but as a description of its local habitat and the methods of hunting.

Having left the Black River [Tschornia Creek] and with it the last timber, we followed up the main stream [headwaters of the Chuya] to a point where it forks, and continued up the left or east branch. At or near these forks I began to observe a good number of sheep heads. It was difficult to guess their age, for even on a live animal the horns often have a cracked and weathered look. I remember but one head in this district where the lower jaw was with the skull. At no very great distance from the forks we turned up a smaller stream to the left and made camp; $3 \frac{1}{2}$ hours' march, which at $2 \frac{1}{2}$ miles per hour would be about $8 \frac{3}{4}$ miles. From this camp, which must be near Demidoff's "Happy Valley," I hunted the afternoon of this day and the whole of the next. The method of hunting is as follows: The guide, Yam-bai, the assistant guide, Mattai, and I, all ride. The country being generally rolling and without sharp ridges it is necessary to keep one's eyes fixed on slopes at a great distance, but it is not necessary to dismount often. When something is sighted, then it is necessary to examine with a good telescope, or when ridges occur one must go up on foot lest he should come suddenly on game. It is extremely uncommon to sight game very close, and when this does occur the country is so open that a successful stalk is almost impossible. The result is that one rides nearly all the time, a method which seemed strange to me at first, but which is the correct thing I am persuaded if one has a far-sighted hunter. The whole matter rests with the keen sight of the hunter. If left to himself the average good American sportsman would loose at least half his chances because he could not see the game before the game saw him.

The country on which sheep are found is of much the same character on both the Russian and Mongolian side of the frontier. It is everywhere absolutely devoid of trees and bushes and covered only with short grass. This grass gives place to shale slopes from time to time, and often one side of the mountain will be washed and weathered, leaving an expanse of broken rocks exposed. Near the tops of many of the hills are often found rocky outcrops of fantastic shapes. The higher mountains which seem to mark the boundary are completely washed, free from grass, their sides covered with rock slides, and extremely rugged.

The sheep are generally found on the open grass-covered slopes, pretty well toward the tops. When in such a position it is obvious that they are very difficult to approach. It is first necessary to get into a position where one can get a good view with a telescope; field glasses are of but little use, the distances are too great. It is then generally possible, by making a sufficient détour, to ride to the foot of the particular hill on which the band of sheep were seen. Sometimes it is even possible to ride a good way toward the desired position on the hill itself. The final stalk itself is always very difficult because of lack of cover, except in those cases where the sheep are found among rocks or near a rock outcrop. The result of the stalk is either a long shot, 300 yards or more, at animals at rest or undisturbed; or a short shot, 100 to 150 yards, at 
animals on the point of flight. If the sheep are on a smooth slope near the top one gets a shot of the second type by coming up hill from the other side. The moment one's head appears above the sky line the sheep are off. The fact that the hills are round topped and without a ridge makes the last moments of the stalk very uncomfortable. To compare this kind of sheep hunting with the pursuit of the bighorn in North America one may say that the physical effort is far less in Mongolia than in North America, but as a rule the final stalk is more difficult. The contrast between the nature of the ground in the two countries may be brought out by the fact that it is nearly always possible to bring horses directly up to the kill in Mongolia.

To return to the narrative of the journey. On the first afternoon as we returned to camp two rams came out on the sky line, but seeing us, departed. On the second day going to the southwest saw a wolf at a great distance but nothing else. Weather very cold with snow. The next day we broke camp and continued up the small valley and over a low and inconspicuous pass, direction east of south. The Mongolian line is probably near this pass; there is a great pile of stones but no stake. The country ahead is high and rolling; to the west are a range of rugged peaks. After crossing a height of land, which I take to be the Bain-Chagan Pass, we proceeded down a valley east of south, and camped on a stream coming in from right, or west, side. March $4 \frac{1}{2}$ hours, say 11 miles. Saw two or three small sheep on hilltops after we had crossed the pass. Our camp ground here had been much used by Kirghiz with their flocks. The next day I tried for sheep both on the west and east sides of camp, but saw none. There are a good number of heads in the valleys, on both sides, showing that rams have been here, and recently.

We continued the journey on July 5 , and turned sharp to right around hills on which I saw a gazelle. The view from these hills to the south and west is striking. The country rapidly flattens out to the south and descends into a valley in which seems to flow a stream. This is perhaps part of the Suok River system. On the other, south, side of this valley high hills, or mountains, rise and extend as far as the eye can see. To the west and south the valley is filled with large buttes of very characteristic and pronounced shapes. Looking down on this part of the valley, the view reminded me of a model of a great mountain system done on a small scale, or of a picture in a school geography. Farther to the west and south, and a good way off, rose a range of high mountains, some completely covered with snow. Later in the morning we came to some water, apparently a branch of the Suok system, and there saw at least 100 ewes and lambs, which came down off a hill and ran over the valley bottom. Saw too a small ram. Having crossed a ridge, we turned due west, into what I am told is the Taylüke Valley. We proceeded west up this valley about 3 miles and camped. Total distance since morning say 15 miles.

The Taylüke Valley, in which we spent 16 days, runs at this point nearly east and west. The valley bottom is perhaps 8,000 to 9,000 feet above sea. On the south side it is bordered by grass-covered hills, which roll with lessening height into a broad valley of a part of the Suok system. The hills on the north side of the Taylüke Valley roll back with increasing height to the boundary range. They are often broken on one side and have a good deal of rock outcrop in places. Sheep were found on both sides of the valley. They showed a preference, however, for the north side. They were not plenty to the east of the place of our first camp, the hills being stony and without much grass; and beyond a point 10 miles to the west they also became scarce. Their range to the north is limited by the barrier mountains and to the south by the Suok Plain. The extent of the range is thus very limited, for the distance from the Taylüke to the high barrier mountains is not more than 2 or 3 miles at the place where the sheep abound. On this range, however, rams are very numerous. Not a day passed that we did not see some. They go in bands of from 6 or 8 to 30 or 40 . I counted one band of 40 rams. The ewes and lambs seem to be in the lower country to the east. Besides one band seen on the march and already mentioned, I saw but one lot of perhaps 30 on the east of the range. 
An average adult ram will carry horns about 19 to $19 \frac{1}{2}$ inches at the butt, and 46 to 48 inches round the curl. Sheep of this size are very common. A few larger heads are to be found in nearly every band; very large heads are of course rarer. I regret that I took no body measurements of sheep. It is safe to say that the animal has a larger body than the average bighorn ram; but it is also certain that the increase in body is not in proportion to the increase in head. In the Ovis ammon the head is out of all proportion to the body. At a distance at this season (July) the rams appear to be of two rather distinct colors-yellowish and black. Near to, the color difference is not so noticeable. It is a characteristic perhaps due to the limited extent of the range that the rams will return time after time to a particular mountain top after they have been driven from it. When alarmed they never hesitate, but dash away until out of rifle shot. Their sight is keener than that of any animal I know. A black servant who accompanied an English sportsman into this region this summer told our men that he had been with the original Demidoff party in 1897, and that then the sheep were tame and comparatively easy to kill. An idea of the number of sheep may be got from the fact that in 15 days' hunting I shot four rams, wounded two, and missed three shots. The number of shots in proportion to the sheep seen was due to the great skill of my head hunter, Yambai, in stalking. It is to be noted that these rams are extremely tough. In my experience they will go farther when mortally hurt than almost any animal I ever saw.

The weather in the valley was bad. About July 8 there were three days when it was unpleasantly warm at noontime; for the rest of the time it was unpleasantly cold. There were few days of continual storm, but there was hardly a day that it did not hail, rain, or snow. The very sudden changes from hot to cold were very trying. If the altitude of the valley is taken at 8,500 feet, that of the hills on which the sheep are found may vary from 9,000 to 11,000 feet. On the hills, often near the tops, I found maral horns, but never a skull. The horns seemed very old. It is to be remembered that there is not a trace of timber in this whole region. Throughout the valley there are signs that it is visited by natives with considerable flocks at some season, but we saw only one party of Kirghiz or Kalmuks, who had got lost trying to cross the frontier, and another party of horsemen, seen at a distance. The number of sheepskins on sale at Kosh-Agatch makes it probable that the natives kill a good many in winter, perhaps in this valley bottom.

I made only two camps in the valley, the last some 6 miles west of the first. On July 22 moved west of north. Three hours' march took us over a steep pass, the Tarkuta, and down into the valley on the other side. On the north side of the pass sheep heads suddenly ceased. It seems pretty certain that the animals in the Taylüke Valley do not cross this divide. The hills in the valley where we camped are more broken than those on the Mongolian side, being covered with rock slides on many of their faces, but their tops are grassy and suitable for sheep. In fact, there is nothing to account for the absence of sheep.

\section{CAPRA SIBIRICA FASCIATA Noack.}

1902. Capra fasciata NoAck, Zool. Anz., vol. 25, p. 623.

1905. Capra sibirica fasciata Trouessart, Cat. Mamm., Suppl., vol. 3, p. 738.

The type-locality of this ibex is on the Bia River, near Lake Teletzkoi, about 70 miles north of Kosh-Agatch. The animal is reported as common throughout the mountains in that vicinity, and numbers of heads and hides are traded at Kosh-Agatch. We were told of the presence of ibex in the mountains near Chibit, on the post road between Kosh-Agatch and Ust-Inya; and one of our men reported seeing one in the mountains near our Tapucha camp, August 7. A

$80459^{\circ}$-Proc.N.M.vol.45-13-34 
fine male was said to have been brought into Tapucha during the time of our stay in the vicinity, but we failed to secure the specimen. I believe ibex are much more common and generally distributed in the mountains between Altaiskoe and Kosh-Agatch than is generally known to the sportsmen who have visited the Altai. This form is probably confined to the wooded country north of the Chuisaya Steppe, on the Siberian side of the ranges, where it inhabits the numerous timberline mountains. Kastschenko reports several specimens of the ibex from the Katoun Mountains and Buchtarme River, southwest of Ongudai and Ust-Inya. In Kosh-Agatch we purchased the skull and horns of a fine old male, killed on the Baskkaous River, which empties into Lake Teletzkoi. This specimen is virtually a topotype of fasciata. The horns are long, gracefully curved, and wide spreading, and the knobs are small and low. This skull, No. 175188, U.S.N.M., measures: Condylobasal length, $270 \mathrm{~mm}$.; greatest breadth, 149; upper tooth row, alveoli, 66; length of horns over curve, 1013 and 1045; circumference at basal knob, 240; distance between horn tips, 810 .

A pet ibex, a young male, which, in company with a young domestic goat of about the same age, enjoyed the entire freedom of KoshAgatch, made friends with us at once on our arrival in town. It followed us into the building given us as camp quarters, and was with considerable difficulty induced to leave, and then only after it had inspected the whole apartments and bounced from the bunk to the table, window sills, and on to the cement stove, or oven.

\section{CAPRA SIBIRICA HAGENBECKI Noack.}

1903. Capra sibirica var. hagenbecki NoAcK, Zool. Anz., vol. 26, p. 381.

1907. Capra sibirica hagenbecki Lonenz, Denkschr. Kais. Acad. Wiss., vol. 80, p. 89.

This ibex, originally described from some point near Kobdo, Mongolia, is common in favorable places on both the Siberian and Mongolian slopes of the border ranges. Our two specimens, killed by Lyman on the Siberian side of Tarkuta Pass (about 35 miles west of Tchegan-Burgazi Pass), July 23 and 24, are both adult males, and agree in every particular with the description of hagenbecki. It is, indeed, likely that the original specimens, on which the form was based, came from much nearer our locality than the town of Kobdo, and the specimens may be assumed to be typical. The headwaters of the Suok River, one of the chief sources of the Kobdo, are not far from Tarkuta Pass.

This is one of the forms without the light-colored "saddle." Our skins, in the short summer coat, have the upper parts of uniform fawn color, blending to almost pure white on the belly. There is a faint narrow dorsal stripe from head to tail. Both specimens have the well-developed callosities on the knee joints, as described of this race, 
and the horns are very heavily knobbed. The two skulls measure: Condylobasal length, 251, $250 \mathrm{~mm}$.; greatest breadth, 145, 146; upper tooth row, alveoli, 71, 72; lower tooth row, 70, 73.5; length of horns over curve, 558, 563; 506, 475; circumference of horn over first basal knob, 260, 251; distance between horn tips, 310, 204.

Lyman's notes contain only one reference to ibex in Mongolia. In the Taylüke Valley, not far from Tarkuta Pass, he "frequently saw ibex on the north side of the valley, among the rocks. They were all females and young, of a rather light yellowish color. They did not confine themselves to broken ground, but often fed on the grassy hill tops." Later on, July 22, after crossing back into Siberia by the Tarkuta Pass, he wrote:

I hunted the mountains to the east and west for ibex. Saw no females, but on the mountain to the west saw two bands of male ibex on two succeeding days, one each day. The first lot consisted of 5 or 6 , from which I shot one. Two or three of these carried horns much larger than the one shot. The second lot I could not count accurately; there were 12 to 18, perhaps, and of these 6 were very large, with horns as large as the head afterwards purchased in Kosh-Agatch. Shot one from this lot. I had a very good look at the large ones as they ran off, and there is no doubt as to the size of their horns. Both bands were feeding on grassy tops, not among rocks. These ibex were not so farsighted as the sheep, and when shot into the bands ran a little way and then stopped to look back before making off. In this they resemble our mountain goat, though not stupid to the same degree. They carry shot remarkably; the second one I killed was hit clean through the body, yet ran more than a mile. The meat of the first ibex was very good eating.

PROCAPRA ALTAICA Hollister.

1913. Procapra altaica Hollister, Smiths. Misc. Coll., vol. 60, No. 19, p. 1, February 8 .

We sighted four gazelles the first day south from Kosh-Agatch, while crossing the Chuisaya Steppe. They started at a good distance and ran directly into a low sweeping cloud of wind, rain, and sand, disappearing as if by magic. The many skins seen in the trading post at Kosh-Agatch were said to come chiefly from the Mongolian side; and though formerly abundant on the Chuisaya Steppe, gazelles are by no means common there at the present day. We had one day in the center of the steppe on our return journey, and I find the following in Lyman's journal regarding the gazelles:

Gazelles on the Kosh-Agatch steppe are scarce and wild. They keep to the open plain and do not get into the foothills, or at least I could find none in that type of country. I saw one band at a great distance on our way southward. On the return journey I devoted five or six hours to hunting and saw but one lot of four males. On the plains it is impossible to get near them. I missed a shot at about 300 yards. Saw also two lots of three or four females and young. My skillful hunter Yam-bai went out by himself for the whole afternoon, but could not get one. This is excellent proof that they are rare and shy in this region. The character of the feed on the KoshAgatch steppe is much the same as that in the foothills near the Suok Plain, Mongolia, thin grass growing on stony, desert-like ground. 
The type-specimen of this gazelle, which is nearly related only to Procapra gutturosa, was shot by Lyman at the point where the trail south from the Bain-Chagan Pass turns westerly, on the edge of the Suok Plain, Mongolia, July 5. In his notes on the game of the trip over the Mongolian border I find a few references to gazelles. He mentions seeing a female soon after crossing the frontier, south of Tchegan-Burgazi Pass; four on the Suok Plain, July 5; and later in the same day, well up among foothills, three or four bunches of five or six each. Later notes mention a few in the Taylüke Valley.

\section{EXPLANATION OF PLATES.}

Plate 37.

Collecting stations in the Altai Mountains.

Upper. Camp on the Chuisaya Steppe.

Middle. Camp on the Tchegan-Burgazi River.

Lower. Camp in the forests of Pinus cembra near Tapucha.

Plate 38.

Natives of the Altai and Habitat of Platycranius.

Fig. 1. Kirghiz marmot hunter and horse.

2. Camp on Tschornia Creek, showing rock slide inhabited by Alticola (Platycranius) strelzovi.

3. Kalmuk horse owner.

\section{Plate 39.}

Scenes in the Altai Mountains.

Upper. Yaks (Pœphagus grunniens) in Alpine meadow.

Middle. Young male ibex (Capra sibirica fasciata) at Kosh-Agatch.

Lower. The "last timber" to the south, on the border of the desert Altais. Larches (Larix sibirica) in valley of Tschornia Creek.

Plate 40.

Skull of Ovis ammon, U.S.N.M. Cat. No. 175180, male, from Altai Mountains, Mongolia. (Greatly reduced).

Fig. 1. Dorsal view.

2. Ventral view.

Plate 41.

Skull of type-specimen of Procapra altaica, U.S.N.M. Cat. No. 175179, Suok Plains, Mongolia (one-fourth natural size).

Fig. 1. Lateral view.

2. Dorsal view.

Plate 42.

Skull and teeth of type-specimen of Procapra altaica, U.S.N.M. Cat. No. 175179, Suok Plains, Mongolia.

Fig. 1. Left upper tooth row, natural size.

2. Left lower tooth row, natural size.

3. Skull, ventral view (one-fourth natural size). 


\section{$2 \mathrm{BHL}$ Biodiversity Heritage Library}

Hollister, N. 1913. "Mammals collected by the Smithsonian-Harvard Expedition to the Altai Mountains, 1912." Proceedings of the United States National Museum 45(1990), 507-532.

https://doi.org/10.5479/si.00963801.45-1990.507.

View This Item Online: https://www.biodiversitylibrary.org/item/31799

DOI: https://doi.org/10.5479/si.00963801.45-1990.507

Permalink: https://www.biodiversitylibrary.org/partpdf/24708

\section{Holding Institution}

Smithsonian Libraries

\section{Sponsored by}

Smithsonian

\section{Copyright \& Reuse}

Copyright Status: NOT_IN_COPYRIGHT

This document was created from content at the Biodiversity Heritage Library, the world's largest open access digital library for biodiversity literature and archives. Visit BHL at https://www.biodiversitylibrary.org. 